\title{
Utilization of Abuscular Mycorrhizal Fungi and Essential Host Plants to Increase Growth of Sandalwood Seeds (Santalum album L.)
}

\author{
Magdalena Sunarty Pareira ${ }^{a}$ dan Yakobus Pffeferius Edvent Saba Agu ${ }^{\mathrm{b}}$ \\ ${ }^{a}$ Fakultas Pertanian, Universitas Timor, Kefamenanu, TTU - NTT, Indonesia, email: mita.pareira89@gmail.com \\ ${ }^{b}$ Fakultas Pertanian, Universitas Timor, Kefamenanu, TTU - NTT, Indonesia, email: jechoforester@gmail.com
}

\section{Article Info}

Article history:

Received 28 Desember 2020

Received in revised form 16 Januari 2021 Accepted 28 Januari 2021

DOI:

https://doi.org/10.32938/sc.v6i01.1243

\section{Keywords:}

Santalum album $\mathrm{L}$

Arbuscular Mycorrhizal Fungi

Host Plants

\section{Abstract}

Sandalwood (Santalum album L.) is one of the native trees of Nusa Tenggara Timur Province because ithas high economic value and is the best endemic species in the world. The essential oil content in it has a very distinctive aroma and can be used to make various products such as handicrafts, wood carvings, incense, and oils for the perfume and cosmetics industry. Sandalwood is a semi parasitic plant whose life requires a host plant to obtain nutrients and water in the soil. There are many types of host plants that have been used, including Casuarina equisetifolia, Acacia mangium, Sesbania grandiflora, Alternantherasp and Capsicum annum. In this research, Sandalwood plants will be tested with the host plant Cymbopogonnardus, which from an economic point of view can provide benefits. Arbuscular Mycorrhizal Fungi (AMF) are a group of fungi from the phylum Glomeromycota which have mutualism symbiosis with higher plant root systems. AMF is able to survive on dry land. The purpose of this study was to analyze the effectiveness of AMF and the use of essential host plants to increase the growth of Sandalwood seeds in Timor Tengah Utara.In the parameter of high increase, the results of the Duncan test showed that the highest AMF treatment for agroforestry land and host chili plants was 19.01, which was different from AMF for Agroforestry land within a host plant, Cymbopogonnardus namely 15.44. In the increase in diameter, the results of the Duncan test showed that the AMF treatment of agroforestry land and host chili plants had a significant ef fect on all treatments, namely 9.11. Duncan test results on plant biomass parameters showed that AMF treatment and host plants chili and lemongrass gave good treatment, namely 3.54 and 3.53 on shoot dry weight parameters and 3.75 and 3.42 root dry weight compared to control, namely 0.27 , while at root and shoot ratio seed quality index, the seeds are suitable for use because they comply with the standard. In the parameters of root colonization, AMF and the host plants of chili and lemongrass were both able to adapt well, namely 56.0 and 54.0.

\section{Introduction}

Sandalwood tree (Santalum album L.) is one of the native tree species of East Nusa Tenggara (NTT) because it has high economic value and is the best endemic species in the world. Sandalwood and its essential oil content have a very distinctive aroma and can be used to make various products such as handicrafts, wood carvings, incense, and oil for the perfume and cosmetics industry (Matsuo and Mimaki, 2010). Sandalwood has contributed to the NTT Province's Original Regional Income (PAD), with wood production of 2,458,594 kg in 1989-1994 (Bano et al, 2001), with an average contribution of $38.26 \%$, and decreased to $12.17 \%$ in 1996-2000 (Kemenhut and Pemprov NTT, 2010) This occurs due to the continuous exploitation of sandalwood without being matched by efforts to replant sandalwood which has resulted in a decrease in the area and quality of its habitat (Haryjanto, 2007). In addition, this condition also occurs due to mismanagement of sandalwood in the past with government policies through local regulations (Njurumanaet al. 2013) which prioritize economic aspects without paying attention to social and sustainability aspects (Butar-Butar and Faah, 2008). Efforts to restore Sandalwood in NTT have been outlined in a systematic and planned manner through the Master Plan and Action Plan for the Development and Conservation of Sandalwood in NTT Province in 2010-2030, namely by planting 4,750,000 sandalwood seeds within four years (Balitbang Forestry NTT 2009). In 2010 the NTT provincial government planned the development of a sandalwood forest with an area of 500 ha on state and communal land (Nusa Tenggara Timor Provincial Forestry Service, 2009b). To support the successful recovery of the sandalwood population, especially on the island of Timor, it is necessary to have an appropriate strategy accordingly. with local conditions.

Another effort that can be made to support the development of sandalwood cultivation is the use of various types of host plants that are appropriate for the purpose of which the host plant can take up nutrients such as nitrogen $(\mathrm{N})$, phosphorus $(\mathrm{P})$, potassium $(\mathrm{K})$, and the necessary amino acids. by sandalwood plants in supporting its growth in the nursery. However, the success rate of growing sandalwood treesin NTT is still very low, due to the lack of information support and technology for sandalwood cultivation and it is difficult to get good seeds. This causes NTT farmers to assume that planting sandalwood with seedlings is difficult, even the possibility of sandalwood not growing (Rahayu et al. 2002), so that in this study, we will try to apply sandalwood trees with economically valuable host plants such as chilies, lemongrass and fungi. Arbuscular mycorrhizal fungi are a group of fungi from the phylum Glomeromycota (Schüßler and Walker, 2010), which have mutualism symbiosis with higher plant root systems (Smith and Read, 2008). The working principle of mycorrhizae is that it can infect the root system of host plants, produce hyphae intensively so that plants containing mycorrhizae will be able to increase their capacity for nutrient absorption (Rungkat 2009). FMA is also able to survive on dry land (Kartika, 2006). These two types of plants are often used because, the host plant purslane has a soft root system, has a small crown, is long-lived, is easy to grow, and can survive in dry land and the host plant of chili has a taproot, is easy to grow, has a value economy (Prajnanta, 2011). Based on the research results of Agustin (2011), AMF was able to infect the roots of chili plants well. This research will also be tested using the essential host plant Cymbopogon nardus L. Cymbopogon nardus is a type of essential oil plant, which is already developed and as a source of foreign exchange because the distillation of its leaves can produce citronella oil which in the world of commerce is known as Citronella Oil. (Damanik, 2007). Therefore, the use of chili and lemongrass host plants and their application with AMF is the best solution to solve the problem of Sandalwood development in TTU on a nursery scale. The purpose of this study was to analyze the effectiveness of AMF and the use of host plants to increase the growth of Sandalwood seeds.

\section{Method}

This research has been carried out in laboratories and greenhouses SEAMEO BIOTROP, from October to December 2018. The tools used are polybags, hoes, rulers, bags plastic, filter, preparation glass, filters oil, refrigerator, microscope, scissors, pipette, tube-centrifuge, and scale analytical. While the material used is a soil sample under a sandalwood stand of 20 grams, trypan blue, and glucose. This study uses an experimental method by identifying and isolating fungi mycorrhizaearbuskula. The design used in this study is a complete randomized design (RAL) with a split-plot design consisting of factor first include:

$$
\begin{aligned}
M 0= & \text { Without Fungi mycorrhizal arbuscular } \\
M 1= & \text { Fungi mycorrhizal arbuskula type of Acaulospora and Glomus. } \\
& \text { The second factor consists of } 3 \text { levels namely: } \\
T 0= & \text { No host plant } \\
T 1= & \text { Chili host } \\
T 2= & \text { Host plant of fragrant lemongrass }
\end{aligned}
$$

From the two factors above there are 6 combinations of treatments performed 3 repetitions times and each repetition consisted of 4 units so that there were 72 seedlings. The combination consists of M0T0, M0T1, M0T2, M1T0, M1T1, M1T2.The soil is weighed as much as 20 grams, then dissolved with $100 \mathrm{ml}$ of water, stirred, and filter uses oil sieves at the size of $212 \mathrm{~mm}$, $106 \mathrm{~mm}$, and $63 \mathrm{~mm}$, that take the remaining soil on the sieve put into the tubecentrifuge which is mixed with $60 \%$ glucose, then distribute at $3000 \mathrm{rpm}$ for 5 minutes. Finished ditrifuse identified brought under a microscope to determine the type of fungi mycorrhizae arbuscular, after knowing the type of fungi mycorrhizae arbuscular directly isolated to each Panama by a treaty it. Some parameters used are plant height $(\mathrm{cm})$, stem diameter $(\mathrm{mm})$, shoot dry weight and root dry weight $(\mathrm{g})$, root shoot ratio is the result of a calculation that compares the dry weight of shoots with the dry weight of plant roots. The analysis used analysis of variance at the $95 \%$ confidence level according to the Completely Randomized Design model with divided plots (Split plot design. Further tests using the Duncan Multiple Range Test (DMRT) at a level of 5\% were carried out if the results of the analysis of variance showed that the treatment had a significant effect.

\section{Results and Discussion}

AMF inoculation had an effect on the growth of Sandalwood as shown in table 1 . The results of analysis of variance showed that this effect was very significant in all observed variables. From these results, Duncan's continued test was carried out on each variable. 
Table 1. Recapitulation of the results of the analysis of the various effects of AMF inoculation on the observed variables

\begin{tabular}{|c|c|c|c|}
\hline \multirow[b]{2}{*}{ Variable } & \multicolumn{3}{|c|}{ Treatment } \\
\hline & $\mathrm{AMF}$ & Host Plants & $\begin{array}{l}\text { Interaction AMF and Host } \\
\text { Plants } \\
\end{array}$ \\
\hline \multicolumn{4}{|c|}{ Increase in heiht $(\mathrm{cm})$} \\
\hline $2 \mathrm{MST}$ & $* *$ & $* *$ & $*$ \\
\hline $4 \mathrm{MST}$ & $* *$ & $* *$ & $*$ \\
\hline $6 \mathrm{MST}$ & $* *$ & $* *$ & $* *$ \\
\hline $8 \mathrm{MST}$ & $* *$ & $* *$ & $* *$ \\
\hline $10 \mathrm{MST}$ & $* *$ & $* *$ & $* *$ \\
\hline $12 \mathrm{MST}$ & $* *$ & $* *$ & $* *$ \\
\hline $14 \mathrm{MST}$ & $* *$ & $* *$ & $*$ \\
\hline $16 \mathrm{MST}$ & $*$ & $*$ & $*$ \\
\hline \multicolumn{4}{|c|}{ Increase in Diameter $(\mathrm{mm})$} \\
\hline 2 MST & $* *$ & $* *$ & $*$ \\
\hline $4 \mathrm{MST}$ & $* *$ & $* *$ & $*$ \\
\hline $6 \mathrm{MST}$ & $*$ & $* *$ & $*$ \\
\hline $8 \mathrm{MST}$ & $* *$ & $* *$ & $*$ \\
\hline $10 \mathrm{MST}$ & $*$ & $* *$ & $* *$ \\
\hline $12 \mathrm{MST}$ & $*$ & $* *$ & $*$ \\
\hline $14 \mathrm{MST}$ & tn & $*$ & $*$ \\
\hline $16 \mathrm{MST}$ & $*$ & $* *$ & $* *$ \\
\hline Shoot dry weight (g) & $* *$ & $* *$ & $*$ \\
\hline Root dry weight (g) & $*$ & $* *$ & $* *$ \\
\hline
\end{tabular}

not real $=P$-value $\geq \alpha(0.05) . M S T=$ Week after planting

\section{Plant Height}

Growth is indicated by an increase in the number and dimensions of plants both in height and diameter. The treatment of AMF inoculation on the increase in height and diameter of Sandalwood plants is shown in figure 1. Each type of AMF inoculated according to the treatment has different added dimensions. The results of Duncan's continued test showed that the highest for height gain was in the M1T1 treatment (AMF and chilli host plants) which was 19.01 different from M1T2 (AMF and lemongrass host plant) which was 15.44 (Figure 1). The highest treatment, the increase in diameter was also in the M1 treatment (Figure 1)

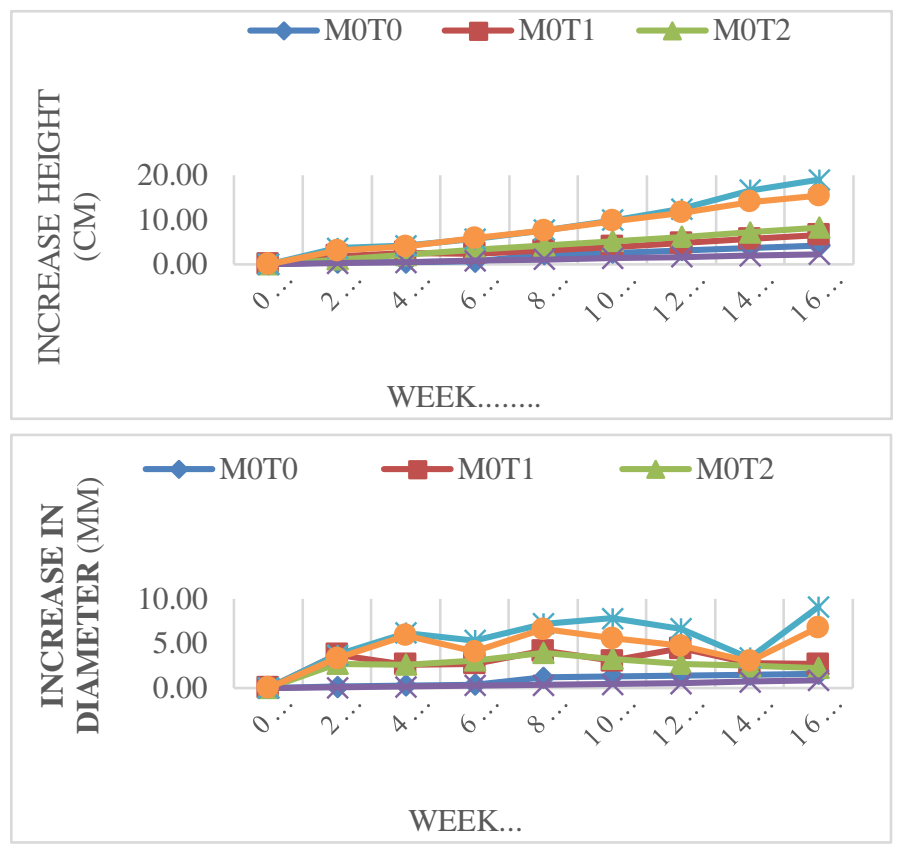

Figure 1. Highest treatment, the increase in diameter was also in the M1 treatment

Figure 1. It shows that the interaction between AMF and host plants gives better sandalwood height increase except for control treatment. This can occur because the inoculum AMF inoculated is AMF obtained from natural habitats that have high adaptation. Mansur (2000) suggested that isolating AMF from local plants would be more effective in increasing local plant growth than using isolates from outside the area. Sandalwood plants inoculated with AMF without a host plant (T0) did not experience a significant increase in height, in contrast to the treatment of host plants without AMF (M0) experienced significant growth. This confirms that the sandalwood plant is semi parasitic, which requires other plants to supply nutrients such as nitrogen, phosphorus, potassium and amino acids needed for growth (Wawo, 2009). The increase in stem diameter (Figure 1) is not always followed by an increase in plant height. The results of the Duncan 5\% test showed that the M1T1 treatment (AMF and the host plant for chili) at the age of 16 MST had a significant effect on all treatments 9.11. This shows that the mycorrhizae used can facilitate the absorption of good nutrients in the soil so that it can increase the growth of chili plants and as a biological barrier against infection with root pathogens, can increase water availability and trigger growth-promoting hormones (Prihastuti, 2007). The lowest diameter value in the control treatment is $1.60 \mathrm{~mm}$, this condition is due to the low and slow availability of N,P, K so that the photosynthetic rate will decrease or be low, so the photosynthate for stem growth will also be limited.

\section{Shoot Dry Weight (g), Root Dry Weight (g)}

Plant dry weight is a commonly used indicator to determine whether or not seedling growth is good, because plant dry weight can describe the efficiency of physiological processes in plants, namely photosynthesis, respiration, translocation and absorption. The results of the Duncan plant biomass test are presented in table 2, these results show that the M1 treatment with the host plant chili (T1) and the citronella host plant (T2) were the best treatments, namely 3.54 and 3.53 on shoot dry weight, and 3.75 and 3.42 on parameters Root dry weight, compared to M1 without a host plant (T0), namely 0.48 . The lowest treatment was in the control treatment M0 which was 0.27 . Plant biomass is also influenced by the role of AMF in absorbing nutrients, especially phosphate, other nutrients, water, and carbohydrates (Smith \& Read 2008).

Table 2. Effect of interactions of Arbuscular Mycorrhizal Fungi and host plants on shoot dry weight and dry weight of sandalwood roots (Santalum album L.) aged 16 weeks after planting

\begin{tabular}{cccc}
\hline AMF local & $\begin{array}{c}\text { control } \\
(\mathrm{T} 0)\end{array}$ & $\begin{array}{c}\text { Host plants } \\
\text { chili } \\
(\mathrm{T} 1)\end{array}$ & $\begin{array}{c}\text { Lemongrass } \\
(\mathrm{T} 2)\end{array}$ \\
\hline \multicolumn{4}{c}{ Shoot dry weight $(\mathrm{g})$} \\
\hline M0 & $0.27 \mathrm{c}$ & $2.75 \mathrm{~b}$ & $2.63 \mathrm{~b}$ \\
\hline M0 & $0.48 \mathrm{c}$ & $3.54 \mathrm{a}$ & $3.53 \mathrm{a}$ \\
\hline M1 & $0.34 \mathrm{c}$ & Root dry weight $(\mathrm{g})$ & $2.52 \mathrm{~b}$ \\
\hline Note: the numbers followed by the same letter show no significant difference at the a 5
\end{tabular}

Note: the numbers followed by the same letter show no significant difference at the $\alpha 5 \%$ level.

\section{Root shoot ratio and seed quality index}

Root shoot ratio (NPA) is an important factor in seedling growth which shows the ratio between the ability of the roots to absorb water and nutrients from the soil with the transpiration process and the area of photosynthesis in the shoots of the plant (Santosa, et al. 2013). Seedlings that are considered suitable for planting if the root ratio value is in the range 2-5. The NPA value of sandalwood seeds in this study ranged from $2.06-4.55$. The highest NPA value in this study was 4.01 in the M1 treatment and the host plant chili, namely 4.01 and the lowest in the control treatment was 0.44 (Table 3). The highest seed quality index was in the M1 treatment and the citronella host plant was 4.78 and the lowest was the M1 treatment without the host plant, namely 0.80 , according to the standard of seed quality (Dickson et al. 1960).

Table 3.Effect of the interaction of AMF and host plants on the root shoot ratio and quality index of Sandalwood

\begin{tabular}{cccc}
\hline \multirow{4}{*}{ AMF local } & \multicolumn{3}{c}{ Host Plants } \\
\cline { 2 - 4 } & \multicolumn{4}{c}{$\begin{array}{c}\text { chili } \\
(\mathrm{T} 0)\end{array}$} & $\begin{array}{c}\text { Lemongrass } \\
(\mathrm{T} 2)\end{array}$ \\
\hline Root shoot ratio \\
\hline M0 & $0.44 \mathrm{c}$ & $2.63 \mathrm{~b}$ & $2.72 \mathrm{~b}$ \\
M1 & $0.56 \mathrm{c}$ & $4.01 \mathrm{a}$ & $3.65 \mathrm{a}$ \\
\hline M0 & \multicolumn{3}{c}{ Seed quality index } \\
M1 & $0.67 \mathrm{dc}$ & $2.81 \mathrm{bc}$ & $2.60 \mathrm{bc}$ \\
\hline Note : The numbers followed by the same letter show no significant difference at the $\alpha 5 \%$
\end{tabular}
level.

\section{Root Colonization}

Colonization of plant roots is characterized by the presence of hyphae, vesicles, arbuscules or one of these structures. In this study, hyphae that infect each plant root include intraradical hyphae and extraradical hyphae which are straight and branched. Hyphae are formed from the germination of spores that play a role in absorbing nutrients and water, which will then be used in the process of growth and development of the host plant. The arbuscular structure has a tree-like shape, which is formed from intraradical hyphae branches that lie between the cell wall and the cell membrane. Arbuscules are very important as a place for the exchange of nutrients between AMF and host plants and as a temporary storage place for minerals, nutrients, and sugar. Vesicles are thinwalled structures that form from the swelling of the tip of a hypha, which are round, oval, or irregular in shape. Vesicles act as food storage organs such as lipids. A high percentage of mycorrhizal colonization will indicate a lot of mycorrhizal infections in the roots. The ability of AMF to infect roots and produce the highest colonization in AMF treatment and chili host plants, namely $56 \%$, was not much different from AMF and citronella host plants, 
namely $54 \%$. The lowest percentage of colonization was in the control treatment, namely $2.0 \%$ (Table 4 )

Table 4. Presentation of Arbuscular Mycorrhizal Fungi Colonization on the roots of host plants of chili and lemongrass, at 16 weeks of age.

\begin{tabular}{cccc}
\hline \multirow{2}{*}{ AMF local } & \multicolumn{3}{c}{ Host plants } \\
\cline { 2 - 4 } & Control (T0) & Chili (T1) & Lemongrass (T2) \\
\hline M0 & $2.0 \mathrm{~d}$ & $24.0 \mathrm{~b}$ & $18.0 \mathrm{cb}$ \\
M1 & $4.0 \mathrm{~cd}$ & $56.0 \mathrm{a}$ & $54.0 \quad$ a \\
\hline Note : The numbers followed by the same letter show no significant difference at the $\alpha 5 \%$
\end{tabular}
level.

Characteristics of Arbuscular Mycorrhizal Fungi.

Table5. Characterization of spore types of arbuscular mycorrhizal fungi from rhizozphere of Sandalwood stands (Santalum album L) on two fields in Timor Tengah Utara after Trapping Results.

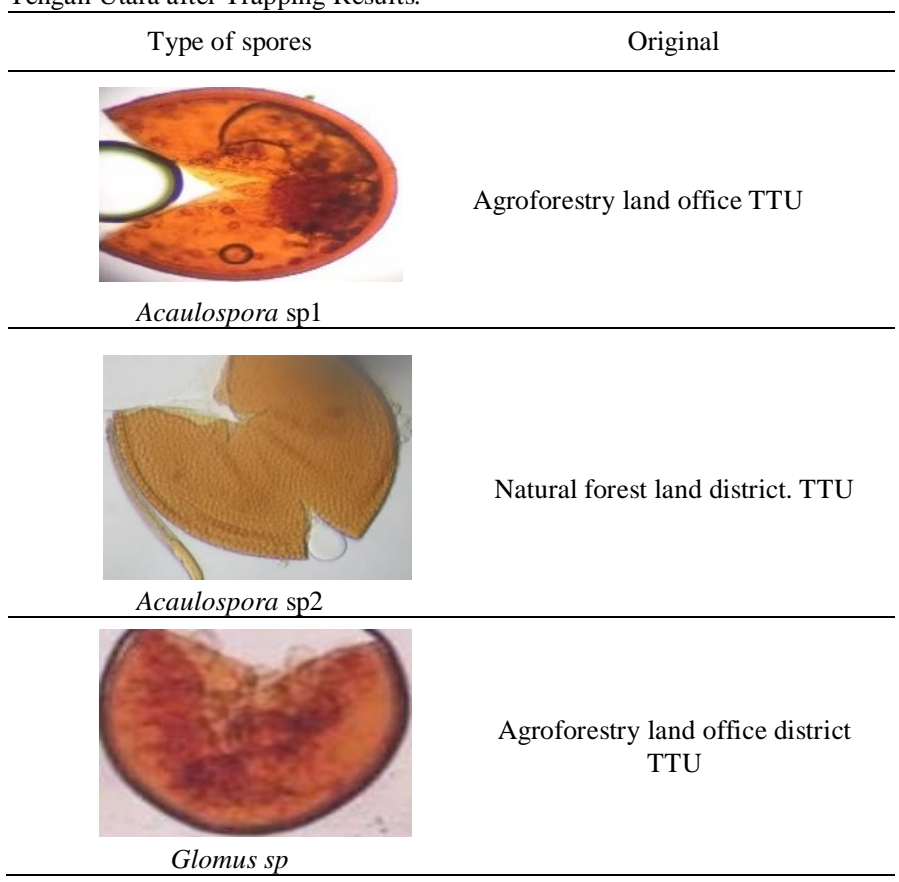

The results of isolation of AMF spore types from the sandalwood stress rhizosphere originating from two fields in TTU district, there are 2 types of AMF spore genera namely Acaulospora and Glomus. The highest AMF spore density was agroforestry land (410/20 g soil), the high AMF population was on agroforestry land due to its diverse or heterogeneous vegetation. The low density of AMF spores is caused by fertilization and loosening of the growing weeds so that they can suppress AMF sporulation. Low value density is found on natural forest land (397/20 g soil) (Table 5)

\section{Conclusion}

Concluded that two AMF genera had symbiosis with sandalwood plants, namely Acaulospora and Glomus, while the host plants used were chili and lemongrass host plants. These two types of host plants can significantly increase the growth of sandalwood plants because they both have the same effectiveness.

\section{References}

Agustin W. 2011. Inoculation of arbuscular mycorrhizal fungi in increasing the productivity and quality of chili seeds (Capsicum annum L) and the efficiency of using $P$ fertilizer [dissertation]. Bogor (ID): Bogor Agricultural University

BanoEt., H., 2001. The Role of Sandalwood in the NTT Economy: Past and Present. Biology News Volume 5 Number 5 August 2001. Special Edition on Sandalwood Issues in NTT. Bogor: Biological Research Center-LIPI. Pp 469-474.

Forestry Research Institute [Balitbang] Kupang 2009. Development of Sandalwood Research and Development in Nusa Tenggara. Kupang (ID): Forestry and Nature Conservation Research and Development Agency.

Butar Butar T, Faah G. 2008. The Need To Improve Sandalwood Management Policies In NTT. Journal of Policy Analysis Vol. 5 No 2: 121-130.

Damanik S. 2007. Economic analysis of lemongrass farming (Case Study of Gunung Halu sub-district, South Bandung district). Journal of the Center for Research and Development of Plantation Bulk LotroVol XVIII No 2: 203-221.

Dickson A, Leaf AL, Hosner JF, 1960. Quality appraisal of white spruce and white pine seedling stock in nurseries. Forest Chron. 36: 10-13.
NTT Provincial Forestry Service. (2009b). Progress of the Development of Sandalwood Forest in East Nusa Tenggara Province in the Context of Realizing the Commitment of the Sandalwood Province: Conditions in June 2009. 97p. Kupang: NTT Provincial Forestry Service

Haryjanto L. 2007. Conservation of Sandalwood Genetic Resources (Santalum album Linn.). Proceedings of the Degree of Sandalwood Technology "Sandalwood for the People: Development of Sandalwood Plants on Community Land", dated 19 December 2006 Puslitbang Forests and Nature Conservation. Bogor. 53-59p.

Kartika, E. 2006. Growth Response, Nutrient Uptake, and Morphophysiological Characters to Drought Stress in Oil Palm Seedlings Symbiosis with CMA [Dissertation]. Bogor (ID): Bogor Agricultural University.

Ministry of Forestry [Kemenhut] and the NTT Provincial Government. 2010. Master Plan for Sandalwood Development and Conservation of East Nusa Tenggara Province 2010-2030. Kupang: Kupang Forestry Research Institute.

Mansur I. 2000. Diversity of rhizobia nodulating the tree legumes Acacia mangiumand Paraserianthesfalcataria and their interaction with arbuscularmycorrhizal fungi in young seedlings. PhD Dissertation, University of Kent at Canterbury, Kent, UK.

Matsuo Y. and Mimaki Y. 2010. Lignans from Santalum album and their cytotoxic activities. Chem Pharm Bull 58: 587-590.

Njurumana GN, Marsono D, Irham, Sadono R. 2013. Community-based sandalwood conservation (Santalum album Linn) in the Kaliwu system on Sumba Island. Environmental Sciences 11 (2): 51-61.

Prajnanta, F., 2011. Overcoming the Problems of Planting Chili. Jakarta: Selfhelp spreader.

Prihastuti. 2007. Isolation and characterization of vesicular-arbuscular mycorrhizae in acid dry land, Central Lampung. Berk. Penel. Hayati: 12 (99-106)

Rahayu, S. Wawo, AH Noordwijk, MV and Hairiah, K. 2002. Cendana (Santalum album Linn.), Deregulation and development strategies. World Agroforestry-ICRAF. Bogor.Indonesia.

Schüßler A, Walker C. 2010. The Glomeromycota. A species list with new families and new genera. Kew (GB): The Royal Botanic Garden Kew.

Smith SE, Read DJ. 2008. Mycorrhizal symbiosis. Third ed. New York (US): Academic Press Soewandito, H. 2008. Study of soil fertility and analysis of land suitability for plantation crop commodities in Bengkalis district. Indonesian Journal of Science and Technology, 10 (2): 128-133

Wawo AH. 2009. Influence of Number of Acacia (SeedlingsAcaciavillosa) and Local Lamtoro (Leucaenaglauca)as Primary Hosts of Sandalwood (Santalum album L.). Bul. Littro. 20 (1): 50-58. 